\title{
ANALYSIS OF THE TYPES OF MAINTENANCE SYSTEMS OF TECHNICAL EQUIPMENT AND THE ASSESSMENT OF THE CHARACTERISTICS OF THESE SYSTEMS FOR SELECTING THE OPTIMAL VARIANT
}

\author{
Ioan VIRCA \\ virca.ioan@armyacademy.ro \\ “NICOLAE BĂLCESCU” LAND FOCES ACADEMY, SIBIU, ROMANIA
}

\begin{abstract}
The use and maintenance of technical systems throughout their lifecycle aims at achieving goals that allow for high values of productivity and availability characteristics of these systems. In the economic policy of each state or private organization or state institution, there is the right to determine the type of adequate maintenance system within the maintenance strategy adopted. Thus, the types of maintenance systems recognized in the technical domain are analyzed from the point of view of the two previously-mentioned features, productivity and availability, thus making the predictive maintenance system, derived from the preventively-planned one, advantageous for all organizations.

It is obvious that the current trend is to spread this predictive maintenance system, according to which the interventions will be carried out before the malfunction occurs, depending on the periodically measured values of global pressure, flow, energy consumption, temperature, current, voltage, vibrations, etc.
\end{abstract}

\section{KEYWORDS:}

Maintenance, availability, productivity, life cycle, operational reliability

\section{Introduction}

Usage and maintenance represent two important stages in the life cycle of a technical system (Băjenescu, 2003, p. 78; Burlacu, Bandrabur, Dăneţ and Duminică, 2011, p. 7), aiming to achieve productivity according to the intended purpose of the system and to ensure a maximum availability state, thus allowing for the fulfillment of the following goals: - safe operation for as long as possible, without failures;

- obtaining functional parameters at equal or close to nominal values, observing the rules of use and work specified in the technical norms;

- applying an appropriate maintenance system, in accordance with the maintenance 
strategy adopted by the firm or organization in question, to allow for the rapid maintenance or restoration of availability by the rational allocation of financial resources;

- the full and quality execution of all maintenance components according to the chosen maintenance system, which is more complex in the case of military technical systems, taking into account their missions and their specifics in the military environment, may be higher in relation to the civilian environment (maintenance, repair, diagnosis, recovery, evacuation, exploitation, reconstruction, etc.) (NATO, 2014, p. 43);

- compliance with occupational safety and health norms and standards of environment protection;

- improving the technical documentation for the use and maintenance of the system, as well as the manufacture of sets or batches of tools, devices, verifiers and the development of software and software products to enable diagnosis and repair processes to be made more efficient, especially for complex technical systems.

Depending on the organization's profile, the level of complexity of maintenance work and the amount of work required, organizations can perform maintenance on their own or outsourced. The adoption of the proper maintenance system is assumed by each organization and meets the legal regulations in the field.

2. Analysis of the types of maintenance systems applicable to the tehnical systems and evaluation of their characteristics

The following types of maintenance systems are distinguished, according to the rhythm of the execution of the works, the level of specialization of the maintenance personnel and the ability to restore the operating state (Lespezeanu, 2000, pp. 58-64; Sisteme de mentenanţă automobile, 2018):

- the maintenance system as required;

- the maintenance system with rigid planning;

- the maintenance system with periodical checks; system;

- the preventively-planned maintenance

- the predictive maintenance system.

Types of maintenance systems

Table no. 1.

\begin{tabular}{|c|c|c|c|c|c|}
\hline $\begin{array}{c}\text { Type of maintenance } \\
\text { system }\end{array}$ & $\begin{array}{c}\text { According } \\
\text { to need }\end{array}$ & $\begin{array}{c}\text { With rigid } \\
\text { planning }\end{array}$ & $\begin{array}{c}\text { With } \\
\text { periodical } \\
\text { controls }\end{array}$ & $\begin{array}{c}\text { Preventively- } \\
\text { planned }\end{array}$ & Predictive \\
\cline { 1 - 5 } $\begin{array}{c}\text { Characteristic } \\
\text { Restoring operating }\end{array}$ & partial & total & partial & total & total \\
\hline $\begin{array}{c}\text { Periodicity of } \\
\text { maintenance } \\
\text { interventions }\end{array}$ & random & rigid & planned & planned & planned \\
\hline $\begin{array}{c}\text { How to organize work } \\
\text { unplanned }\end{array}$ & planned & $\begin{array}{c}\text { partially } \\
\text { planned }\end{array}$ & planned & planned \\
\hline $\begin{array}{c}\text { Complexity of works } \\
\text { diversified (from } \\
\text { simple to } \\
\text { complex })\end{array}$ & complex & average & high & high \\
\hline $\begin{array}{c}\text { Effective time of the } \\
\text { total resource }\end{array}$ & diminished & accomplished & accomplished & accomplished & accomplished \\
\hline
\end{tabular}




\begin{tabular}{|c|c|c|c|c|c|}
\hline $\begin{array}{c}\text { Type of maintenance } \\
\text { system }\end{array}$ & $\begin{array}{c}\text { According } \\
\text { to need }\end{array}$ & $\begin{array}{c}\text { With rigid } \\
\text { planning }\end{array}$ & $\begin{array}{c}\text { With } \\
\text { periodical } \\
\text { controls }\end{array}$ & $\begin{array}{c}\text { Preventively- } \\
\text { planned }\end{array}$ & Predictive \\
\cline { 1 - 5 } Qharacteristic & universal & specialized & $\begin{array}{c}\text { on average } \\
\text { specialized }\end{array}$ & specialized & specialized \\
\hline $\begin{array}{c}\text { Information on the } \\
\text { degree of wear of the } \\
\text { assemblies }\end{array}$ & reduced & complete & complete & $\begin{array}{c}\text { complete, over } \\
\text { a large interval }\end{array}$ & complete \\
\hline $\begin{array}{c}\text { Time of } \\
\text { immobilization / } \\
\text { revision }\end{array}$ & reduced & reduced & average & average/high & average \\
\hline $\begin{array}{c}\text { Immobilization time } \\
\text { total resource }\end{array}$ & reduced & average & average & average & reduced \\
\hline $\begin{array}{c}\text { Cost of maintenance } \\
\text { intervention }\end{array}$ & reduced & average & average/high & high & high \\
\hline $\begin{array}{c}\text { Utility and } \\
\text { implementation }\end{array}$ & necessary & useful & useful & very useful & very useful \\
costly & costly & costly & costly \\
\hline
\end{tabular}

The current trend, especially for manufacturing, surveillance and assistance technical systems characterized by a high degree of automation, is to adopt the predictive maintenance system (Mentenanţa, 2018).

This system consists in executing technical interventions when a series of the tested parameters (pressure, flow, temperature, vibration, speed, fuel consumption etc.) indicate an inadequate start in the functioning of the technical system, which implies the allocation of important financial resources, the maintenance works being executed prior to the failure of the components of the technical system. Table no. 1 summarizes the characteristics of each type of maintenance system.

The following types of maintenance systems are distinguished, according to the rhythm of the execution of the works, the level of specialization of the maintenance personnel and the ability to restore the operating state:

- the maintenance system as required;
- the rigidly planned maintenance system;

- the maintenance system with periodic checks;

- the preventively-planned maintenance system;

- the predictive maintenance system.

For hierarchical and centralized organizations, where labor and consumption of spare parts and materials are normalized and the budget allocation is anticipated, a preventively-planned maintenance system is appropriate, which is based on annual maintenance plans correlated with an appropriate logistical system.

Under the preventively-planned maintenance system, the manufacturer establishes for each technical system the periodicity and volume of compulsory works/operations for each technical intervention resulting from the product use traceability, based on the calculation of the wear and tear of the parts and according to the nomenclature and cycle of technical interventions. 


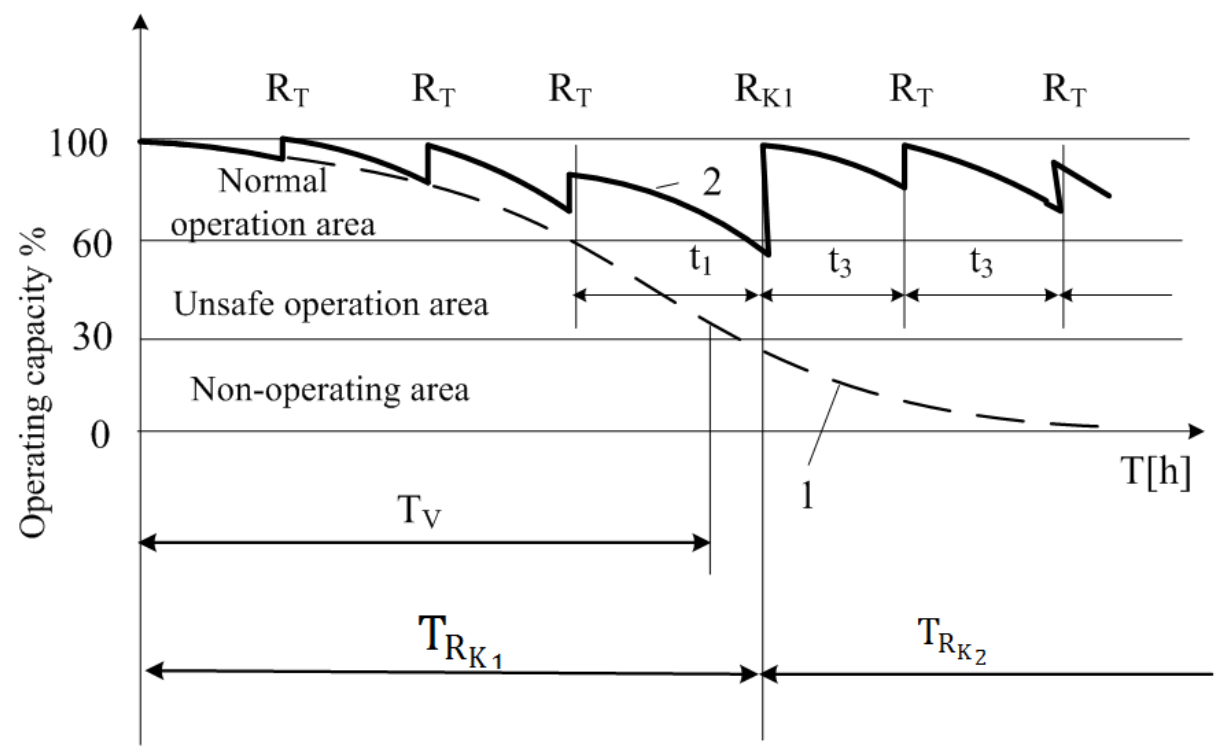

Figure no. 1 The scheme of executing technical interventiona in the planned preventive system

1 - The evolution curve of the technical condition in the absence of technical interventions 2 - The curve of the evolution of the technical state in the situation of performing the technical interventions

In Figure no. 1, there is a schematic representation of the evolution of the technical state and of the functional capacity of a technical system along its life cycle in which the technical preventive and corrective interventions are performed according to the specific rules of a planned preventive maintenance system. As can be seen from the graph, the technical preventive interventions are executed after a rigid planning. The technical repairs (TR) are executed as required, and the highcomplexity (KR1) and so on repairs are performed after a flexible planning, including the prior checking of the technical condition.

The effective operating time $T_{V}$ of the technical system is very close to what is possible. Theoretically, this duration can be greatly prolonged by repeating the cycles of technical preventive and corrective interventions. Practically, this duration corresponds to the moment when the highgrade repair (KR) becomes unprofitable.

The advantages of the preventivelyplanned maintenance system are:
- the planning and management on a scientific basis (lifecycle, repair cycle, inspection rules, maintenance and repair, consumption norms, spare parts and materials, technical inspection norms and special materials transport, maintenance infrastructure etc.) of the maintenance activity, based on an annual plan;

$$
\text { - avoiding the accidental }
$$
decommissioning of the technical systems due to the scheduled periodic interventions, except for the damages that may occur in exceptional cases (hidden manufacturing defects, excessive wear, heavy use, nonobservance of technical maintenance rules etc.) with low probability;

- increasing the effective functioning time of the technical systems by maintaining a high availability and the possibility of extending the repair resource or the total operating resource;

- the full implementation of the planned technical preventive interventions, at the established deadlines and in the prescribed volume, through the planned 
annual allocation of the financial resources in the budget planning documents specific to the organization.

The disadvantages of the preventivelyplanned maintenance system are:

- the execution of a prescribed large volume of corrective operations particularly leads to long halting times in major repairs and costs, sometimes failing to identify the defects or failure premises, the dismantled assemblies being in fact in running condition;

- making unnecessary expenses determined in particular by the workmanship used to fully carry out the prescribed work, and in stock there must be spare parts which may not be immediately necessary.

Due to these aspects, in the technological process of maintenance, it is necessary to introduce rapid and effective diagnostic systems for checking and assessing the technical condition in order to ensure a high operational reliability (Lespezeanu, 2000, p. 136, 138).

Within the military system, there are tendencies on the part of specialists to apply the maintenance strategy based on operational reliability to all the military technical systems in the equipment, having the characteristics of the predictive maintenance type. This is used by many states of the North Atlantic Treaty Organization and demonstrates a high efficiency compared to other known and applicable systems.

The strategy under discussion implies taking into account the working objectives and the allocation of the financial, technical and human resources specific to the operational reliability category, being based on the "processing of the data obtained from the exploitation, i.e. on the basis of the exploitation of several identical specimens, for a specified period of time".

\section{Trends and conclusions}

Military technical systems now have a great construction-functional diversity due to the multiple missions the military system performs, as well as the current technological evolution in the technical field and the combined forms of military action.

The military technical systems can be found in all military weapons, specialties and services such as: armored combat, special purpose vehicles, armament systems, command and control systems, communications and control, engineering equipment and devices, nuclear, biological and chemical detection equipment etc.

This diversity of technical systems involves a complex structure, organized in all the possible forms presented above, from the simplest to the combined structures, often made in functional or modular blocks.

There is currently a tendency to modulate some component systems or subsystems due to the advantages of these variants (Virca \& Badea, 2016):

- rapid replacement of faulty functional blocks;

- the possibility of performing on different chassis or the same basic structure of different functional blocks and their use depending on the task or task at work;

- reduction of design and manufacturing costs for the basic structure;

- increasing the degree of specialization of the maintenance personnel for the basic structures;

- reduction of maintenance and maintenance costs in repair;

- decrease in the transport volume of modular technical systems and associated costs, due to the reduction in the number of basic structures, etc.

As such, military technical systems require both preventive and corrective maintenance, organized on levels of complexity depending on the nature of the maintenance intervention, the scale of the works and the level of competence of the maintenance organization.

Also, given the different age of the technical systems since their entry into their possession, it is necessary to apply differentiated preventive and corrective maintenance. 
The current system of preventivelyplanned maintenance works involves the allocation of significant financial funds over the lifecycle of technical systems resulting from the life cycle cost analysis (Bucoveţchi, Badea, Oancea and Stanciu, 2018, pp. 181-192), but it allows maintaining a high availability of the existing equipment.

This state of availability can be expressed by the $\mathrm{CO}$ coefficient of efficiency $\mathrm{CO}=\mathrm{B} / \mathrm{N}$, which represents the value of the ratio between the number of technical systems in running order (B) and those required $(\mathrm{N})$ provided in the states of organization or the organization chart of the firm/institution.

For the military system, this coefficient is of particular importance, especially during times of crisis and war when its value significantly influences the engagement of combat missions in all its forms of action.

The good functioning of military technical systems is largely due to the way in which maintenance activities are organized during their use. The optimal operation of military technical systems with minimal costs for the planned repairs, revisions and maintenance and without any production losses cannot be achieved through the classical methods of corrective maintenance, which solves the defects of the military technical systems only at the moment of their occurrence.

In this case, it becomes necessary to implement the predictive maintenance type in the life cycle of the technical systems, which means the identification of the ,key points" in the functioning of the technical systems and the intervention on them before the appearance of the defects.

\section{REFERENCES}

Băjenescu, T.I. (2003). Fiabilitatea sistemelor tehnice. Bucureşti: Matrix Rom.

Bucoveţchi, O., Badea, D., Oancea R., \& Stanciu, R. (2018). Considerations on modelling resilience governance for decision support systems. University Politehnica of Bucharest Scientific Bulletin, Series B, Vol. 80, Issue 2, 181-192.

Burlacu, G., Bandrabur, C., Dăneţ, N., \& Duminică, T. (2011). Fiabilitatea, mentenabilitatea şi disponibiloitatea sistemelor tehnice. Bucureşti: MatrixRom.

Lespezeanu, I. (2000). Mentenanţa autovehiculelor. Bucureşti: Editura Academia Tehnică Militară.

Mentenanţa. Note de curs 1, available at: https://memm.utcluj.ro/materiale didactice/mentenanta/curs/Mentenanta note de curs 1.pdf, accessed on 05 December 2018.

North Atlantic Treaty Organization, NATO Standardization Agency (NSA). (2014). AAP-6. Glossary of terms and definitions. Bruxeles: Author.

Sisteme de mentenanţă automobile. available at: http://www.creeaza.com/ tehnologie/auto/Sisteme-de-mentenanta-a-automo714.php, accessed on 05 December 2018.

Virca, I., \& Badea, D. (2016). Armored wheeled fighting vehicle using a variant of modular construction model. Revista Academiei Forţelor Terestre, no. 4 (84). 